\title{
Introduction: Religion in the Making of a Region
}

\author{
Nikita Sud, University of Oxford
}

and

\section{Harald Tambs-Lyche, Universite de Picardie Jules Verne}

Religion is experiencing a revival in the academy. It is being varyingly discussed across the disciplines as a source of radicalisation, ${ }^{1}$ a marker of identity politics, ${ }^{2}$ an entity that is challenged by the attraction and pressure of homogenising reform versus pluralistic proliferation, ${ }^{3}$ a social structure of accumulation in the economy, ${ }^{4}$ an actor in fields such as education, health and community development, ${ }^{5}$ a source of well-being, ${ }^{6}$ and an anchor from the stresses of globalisation. ${ }^{7}$

These many facets of religion have been 're-discovered' after having been pushed to the background of social enquiry and political application in the era of modernisation. Influenced by the European Enlightenment, states and nations, first in the global North, and then in the

\footnotetext{
${ }^{1}$ K. Neuhouser, 'The Radicalization of the Brazilian Catholic Church in Comparative Perspective', in American Sociological Review, Vol.54, no.2 (1989), pp.233-44; and A. Rashid, Taliban: The Story of the Afghan Warlords (London: Pan MacMillan, 2001).

${ }^{2}$ C. Jaffrelot, The Hindu Nationalist Movement and Indian Politics (London: C. Hurst \& Co., 1996).

${ }^{3}$ K.D. Breault, 'New Evidence on Religious Pluralism, Urbanism, and Religious Participation', in American Sociological Review, Vol.54, no.6 (1989), pp.1048-53.

${ }^{4}$ B. Harriss-White, India Working (Cambridge: Cambridge University Press, 2003).

${ }^{5}$ C. Candland, 'Faith as Social Capital: Religion and Community Development in Southern Asia', in Policy Sciences, Vol.33 (2000), pp.355-74.

${ }^{6}$ C.G. Ellison, 'Religious Involvement and Subjective Well-Being', in Journal of Health and Social Behaviour, Vol.32 (March 1991), pp.80-99.

${ }^{7}$ R. Royal, 'Globalization and Italian Culture', in P. Janni and G.F. McLean (eds), The Essence of Italian Culture and the Challenge of a Global Age (Washington DC: The Council for Research in Values and Philosophy, 2003), pp.53-65.
} 
post-colonial South, were expected to tread the path of rationality, science and secularism. As one of the first southern countries to attain Independence, India adopted the mantle of modernisation with gusto. As a secular state it was required to govern a multi-religious nation. The prevailing belief was that religion would become less and less relevant as the nation embraced modernity.

While some scholars have kept up a sustained criticism of the state's attempted secularism as an imposed import from the West, ${ }^{8}$ even committed secularists would concede that the Indian state and polity are deeply embedded in religion. The decline in the one party dominance of the Congress Party through the 1970 s and beyond has seen a broadening of democracy and democratic contenders. The appeals of this widening political spectrum have often been along the lines of caste, region, and religion. The most successful experiment in politicised religion has come from the Hindu Right, led by its ideological core, the Rashtriya Swayamsevak Sangh (RSS), which together with its family of organisations has been part of Indian public life for much of the twentieth century. But it is only in the wider political space of the 1980s that these organisations have been able to make their mark as the representatives of a homogenised, majority-Hindu community in spheres as diverse as politics, education, culture and development. The political face of the RSS, the Bharatiya Janata Party (BJP), has held power in India at various points from 1998, and it still rules several Indian States ${ }^{9}$ today.

\footnotetext{
${ }^{8}$ P. Chatterjee, The Nation and Its Fragments: Colonial and Postcolonial Histories (Princeton: Princeton University Press, 1993); T.N. Madan, Modern Myths, Locked Minds: Secularism and Fundamentalism in India (New Delhi: Oxford University Press, 1997); and A. Nandy, 'The Twilight of Certitudes: Secularism, Hindu Nationalism and other Masks of Deculturation', in Postcolonial Studies, Vol.1, no.3 (1998), pp.283-98.

${ }^{9}$ In this Introduction and all the papers that follow, state with a small ' $\mathrm{s}$ ' refers to the institutional apparatus of government, with its attendant norms, ideologies and politics. State with a capital ' $S$ ' connotes the federal units of the Indian union. Princely states, since they represent both a form of government and territory, are not capitalised.
} 
Gujarat, the focus of this special issue, is a Hindu-nationalist poster boy, with the BJP having held power in the State intermittently from 1990, and continuously from 1998. This period has witnessed a reign of terror unleashed on the minority Muslim and Christian communities. Christian churches and schools have been attacked, couples in inter-religious marriages hounded, and periodic mass violence has been orchestrated by Hindu nationalists and their supporters. The state has mostly condoned this aggression against its religious minorities. The worst example came in 2002, when Gujarat hit national and international headlines in the aftermath of the massacre of up to 2000 Muslims during the tenure of the BJP government of Chief Minister Narendra Modi. It is widely believed that the government was actually complicit in the 2002 violence, with participation from the highest officials down to the local police. $^{10}$

For many, the events of 'Gujarat 2002' represented a paradigm shift in Indian politics. Over time, the land of non-violence espoused by Gandhi has been forged into a Hindu rashtra or Hindu nation-state of, by, and for Hindus, through the sustained efforts of the Right. That the protagonists of the Right believe this is so is clear from placards they have placed in prominent locations across numerous Gujarati towns and villages; these welcome the visitor to 'Ambaji Pradesh of Hindu Rashtra', 'Naroda Pradesh of Hindu Rashtra' and the like, which infer that these regions are being proclaimed as pradesh or provinces of the Hindu land of Gujarat.

\footnotetext{
${ }^{10}$ V.R.K. Iyer, P.B. Sawant, H. Suresh, K.G. Kannabiran, A. Roy, K.S. Subramanian, G. Shah and T. Sarkar, Crime Against Humanity. An Inquiry into the Carnage in Gujarat, 2 Vols. (Mumbai: Citizens for Justice and Peace, 2002); S. Varadarajan, Gujarat: The Making of a Tragedy (New Delhi: Penguin, 2002); and D. Bunsha, Scarred: Experiments with Violence in Gujarat (New Delhi: Penguin Books, 2006).
} 
The resurgence of religion in Gujarat fits global trends, which are in turn reflected in increased academic attention. The appeal of politicised religion appears to lie in a rejection of 'pseudo-secularism', in the derisive language of the Hindu nationalists, as an alien modernity. Further, the broad acceptance of religion in politics, and the overt visibility of religious symbols and figures in the public sphere, has been attributed to the unsettling influence of globalisation and liberal economic reforms. This harking back to a constructed sense of rootedness and community has been interpreted as a quest for security and familiarity in a time of change. ${ }^{11}$ The latter explanation seems especially appropriate for Gujarat, given its status as a front-runner in India's neo-liberal growth story. While we do not entirely dispute these inferences, our attempt is to suggest a fresh narrative in this special issue.

To begin with, this Introduction offers a brief history of the making of the region of Gujarat. Far from being ' $a$ ' nation-state, Hindu or otherwise, Gujarat is a space riven with past schisms which have implications for contemporary politics. Following this, we move to a discussion of religion in the production, reproduction, and at times endangering, of the region. The contributions to this volume are intended to provide depth to the story of Hindutva in Gujarat, by highlighting some of the institutions, structures and actors that comprise this phenomenon. But our purpose is also to move beyond Hindu nationalism, to explore at least some of the quotidian religions, sects and communities that criss-cross the history, geography, economy, society and politics of this land, offering faith, and also identity, to its diverse peoples. The historical and ethnographic papers presented here perform this function.

\footnotetext{
${ }^{11}$ T. Basu, P. Datta, S. Sarkar, T. Sarkar and S. Sen, Khaki Shorts and Saffron Flags. A Critique of the Hindu Right (New Delhi: Orient Longman, 1993); and S. Corbridge and J. Harriss, Reinventing India. Liberalisation, Hindu Nationalism and Popular Democracy (Cambridge: Polity Press, 2000).
} 


\section{The Making of a Region}

Like most nation-states, the region now called Gujarat is the product of a specific, historical development whose construction combines organisational and ideological elements. Today, the region is generally seen as coterminous with Gujarat State, formed by the division of the erstwhile Bombay State along linguistic lines in 1961. This linguistic divide implied that divergent regional dialects, notably Kutchi and Kathiawadi, came under the general heading of Gujarati, as opposed to Marathi in the part of Bombay that was to become Maharashtra.

At the time of separation, the main point of conflict was the inclusion of Bombay in Maharashtra, opposed by the Mahagujarat movement among Gujaratis, but also by vocal parts of the Bombay elite-largely Gujarati speakers - who would have preferred the city to constitute a separate 'city-state' of the Indian Union. The inclusion of Kutch and Saurashtra — formerly called Kathiawar-in the State of Gujarat did not raise much of a problem at the time. Yet, even today, there is a strong feeling of regional identity in Kutch, and this is to some extent true of Saurashtra too.

This feeling of separateness has a long history related to the past of these two regions, which were administered as princely states rather than, as most of central Gujarat was, directly as part of British India. The same applies to a number of princely states in the north of the region, and the Portuguese enclaves of Diu, Daman, Dadra and Nagar Haveli. Finally, the eastern fringe of the State includes an important tribal element, especially in the south. What we have before us, then, is a mosaic of political units that characterised the region in colonial times. 
These divisions have quite a long history. From at least the eleventh century we find 'Sorath' (Saurashtra, mainly the western part dominated by Junagadh) opposed to 'Gujarat', which then refers to the central continental plain of the Sabarmati and Mahi rivers. In literature even older than that, Lata, the present area of coastal Gujarat south of Bharuch, was often described as a separate region. Yet at least since the eleventh century, the continental plainfrom Khambhat to the then capital, Anhilwada Patan and northwards - has formed the base of strong political formations, the Solanki or northern Chalukya kingdom at first, then the Sultanate of Gujarat from 1407 to 1573, after which Akbar conquered the area. The centre of Mughal administration of Gujarat continued to be Ahmedabad, however, which was founded by the sultan, Ahmed Shah, in 1411.

The Chalukyas, as well as the sultanate and later the Mughals, followed an expansive policy and generally tried to maintain overlordship over Saurashtra and surrounding regions. Kutch, however, often escaped domination. It was the largest and generally the strongest of the numerous Rajput states that bordered central Gujarat to the west. Junagadh fought with its continental neighbour frequently, until conquered by Sultan Mahmoud Begada of Gujarat in 1470. He extended the power of the sultanate eastwards, and Gujarat, under his rule, largely coincided with the present State's boundaries, with the exception of Kutch.

To the east, powerful Rajput states like Mewar (Udaipur) and Marwar (Jodhpur) set the limits of political expansion. But most of the Rajput chiefdoms to the west of the central Gujarat plain were small and no match for forces from the mainland. They regained a measure of independence, however, as Mughal power waned in the eighteenth century, even though the Marathas, centred in Baroda, tried hard (but unsuccessfully) to establish hegemony in the region. 
Then came the British. The different policies they followed in Saurashtra and Rajasthan may have contributed to the present delimitation of Gujarat. In Saurashtra, Colonel Walker signed separate agreements with more than 200 chiefs. While Walker acknowledged certain dependence relations between these states - notably the tribute paid as zor-talabi by many of the states to Junagadh, as well as the tribute paid to the Marathas in Baroda- these relations did not modify the various rulers' rights and obligations towards the British: each state dealt with the paramount power separately. In Rajasthan, a generation later, the Orienalist scholar James Tod proceeded very differently: he stressed the relations between the larger states and their vassals, so that the British only recognised and dealt individually with a much smaller number of rulers. The extreme fragmentation of power in Saurashtra-under the Western India States Agency_enhanced paternalistic relations between local power and the British, and strengthened the centre-periphery association between the plains of central Gujarat and the peninsula. Rajasthan, on the other hand, was seen as a region entirely disconnected from, and different to, Gujarat. Sindh was separated from Kutch by the Rann, a salty desert partly under water in the rainy season, and here, again, the colonial regime was constituted differently.

The beginnings of the Indian independence movement were urban, and largely confined to an elite. But central Gujarat, with its Patidar farmers, was probably the first region where the movement made a direct appeal to farmers. There was no similar effort to mobilise the rural population of the princely states, and in 1938 when the Congress attempted a satyagraha at Rajkot, in central Saurashtra, it was a failure. ${ }^{12}$ The local opponents of the action managed to

\footnotetext{
12 J.R. Wood, 'Indian Nationalism in the Princely Context: The Rajkot Satyagraha of 1938-1939', in R. Jeffrey (ed.), People, Princes, and Paramount Power. Society and Politics in the Indian Princely States (New Delhi: Oxford University Press, 1978), pp.240-74.
} 
stigmatise the move as one initiated by 'outsiders', Brahmins and Banias with their main loyalties in central Gujarat.

There were, in fact, differences in the caste order between central Gujarat and the surrounding areas. In the centre, trade had been important since very early times, and until the rise of Bombay, the region formed the node of Indian Ocean trade, and the Portuguese, the British and other Western powers used the term Gujarat to connote the area. Merchant communities there enjoyed a power and a prestige unequalled elsewhere in India. Together with Brahmins, who often worked as administrators or traders, they formed a bourgeoisie which proved to be highly receptive to modern influences under colonial rule, including the movement for independence, and Gujarat — which by that time was designated the mainland area, excluding Saurashtra and Kutch-became a centre of the movement. By contrast, sympathy for the movement was only sporadic in the princely states. There, it was largely centered on a bourgeoisie which was limited in power and influence by the agrarian nexus, built on traditional 'feudal' loyalties from agriculturalists and artisans, through local landlords who were often Rajputs, and up to the princely families. The latter generally opposed the independence movement, aware that there might be no place for them or their states in an independent India.

With Independence, the relationship between central Gujarat and the surrounding princely states became, to an extent, the relationship between a rising bourgeoisie in the former and an aristocratic elite in disarray in the latter. Indeed, following some armed resistance by landlords and members of princely families in Saurashtra, the 1952 elections delivered an overwhelming victory for the Congress, led by the Brahmin- and Bania-dominated bourgeoisie. The promise of land reform, which removed the power base of the old elite, was 
probably the main factor behind the victory. Patidars, often recent immigrants from the mainland, where they had been active in the independence movement, were the biggest winners in these land reforms. This was to the detriment of the locally-dominant Rajputs. Kolis, who often were tenants and land labourers, did not profit from the land reforms to the same extent as the Patidars. Thus the 'winners' in 1952 were those groups that had close links to the centre of Gujarat, while the 'losers' were those that tended to stress the particularity of the region and its difference from the centre. These events strengthened the centre-periphery dimension of the region that was to become Gujarat, so that the inclusion of the 'peripheries' in the State formed in 1961 seemed 'natural' to its dominant groups. Only with the political rise of the Other Backward Castes and the corresponding reaction against them from the urban elite in the 1980s, did a challenge to Bourgeois-Patidar domination become feasible. Needless to say, the upsurge of the backward castes was violently put down by a Savarna or upper-caste grouping, led by an up and coming BJP. Through the 1990s and beyond, the elites that dominate the party and its broader Hindutva coalition have held on to power in the State; some would suggest with the instrumental use of religion functioning as a mass electoral ploy.

Overall, taking a longer-term view, the creation of the present Gujarat State is heavily predicated on the struggle between the modern, bourgeois-dominated democracy that India was to become, and the residues of an earlier 'feudal' order, struggling yet unable to withstand the pressures of the Independence period.

\section{Religion and the Making of the Region}

The extreme violence of 2002 shocked many, and served to catalyse a number of studies. Several of the authors in this volume use 'Gujarat 2002', or the popularity of Hindu 
nationalism in the State, as an entry point into their papers. However, most quickly move beyond the monolithic identities hewn by politicised religion, be they of the majoritarian variety or those propagated by, say, Islamic reformers who have attempted to assert their position in a time of insecurity. This broadening of the agenda is entirely justifiable and much needed. We have before us, after all, a region that has been at the centre of longstanding Indian Ocean trade networks, thus becoming a mélange of peoples and their attendant faiths, sects and cultures. ${ }^{13}$ Counter-intuitively, though perhaps logically, merchants and mercantile sensibilities, and not priests, have dominated its religious traditions (Tambs-Lyche, this volume). Even today, Hindu nationalism rides on a wave of capitalist, neo-liberal growth (Desai, this volume). At the same time, it reaches out to its poorer constituencies through grass-roots work centred on access to, or at least the promise of access to, civic amenities through patronage (Berenschot, this volume). Questions of pride, agency and religiosity thus intermingle, as they always have, with the business of everyday living (Chaturvedi, this volume).

In addition to adding nuance to the story of politicised religion and religious domination in Gujarat, we seek to demonstrate the porousness of the religious experience in this frontier State. Even as reformers attempt to introduce conformity, Gujarat evinces varying forms of syncretism, personalised faith, vernacular devotionalism and micro-religious traditions which challenge established social and cultural, but also political and geographical, boundaries (see Heitmeyer, Ibrahim, Sheth and Simpson, this volume). Gujarat may well be home to 'successful', and dangerous, religious nationalist and fundamentalist experiments; but it is also a space where these inclinations are challenged, frustrated and circumvented on a daily

\footnotetext{
${ }^{13}$ S. Sheikh, Forging a Region. Sultans, Traders, and Pilgrims in Gujarat, 1200-1500 (New Delhi: Oxford University Press, 2010).
} 
basis. Our region of interest was never a simple, uni-dimensional arena. As scholars, we must resist any attempts to portray it as such.

The following paragraphs provide snapshots of the essays that comprise this special issue. In an innovative paper, Harald Tambs-Lyche suggests that a merchant religion dominates Gujarat's Hindu landscape. The author places his analysis within the long vibrant history of trade and commerce in the region. He traces the emergence of a powerful merchant class, its undulating relationship with state power, and its steady ascent in the region's religious milieu. The economic and social capital of the merchants of Gujarat, combined with the unsteady fortunes of a string of rulers, ensured that the mercantile emphasis on purity, nonviolence and vegetarianism has had a lasting impact on the region's sacred geography. This has sidelined the Shakti religious traditions of the ruling Kshatriyas, and the elitism of the Brahmins, as well as other folk religions. In the present day, powerful sects such as the Swaminarayans have followed and promoted a mercantile ethos of religious purity and social mobility, further entrenching the position of merchant religion in Gujarat.

In a fascinating insight that takes this bird's-eye view to the twentieth century and beyond, Tambs-Lyche connects the positive reception of the Gandhian philosophy of non-violence to the basis laid for this idea in the preceding centuries. Similarly, he shows us how the ascendant mercantile ethos, combined with the underpinnings of an encompassing religious tradition, have been able to dominate current social and political life. Merchant religion, which encourages an aspirational outlook across the boundaries of caste, may well explain the formation and sustenance of a Savarna Hindu community in a time of Hindu nationalism. Taking our understanding of contemporary Hindutva politics back by several centuries, the 
author moves us a step closer to explaining the endurance of Gujarat's particular brand of regional politics.

Even as Hindu nationalism thrives on the base of a mercantile culture, our next three authors highlight the structures and actors that produce and reproduce this dominant paradigm. Adopting a macro perspective, Radhika Desai indicates that the electoral features of Hindutva vary across Gujarat and India. We may see the ideology and its politics expressed in some regions more strongly than in others. However, its entrenchment in the neo-liberal project means that Hindu nationalism is going to be a fairly enduring political force, albeit not an unchanging or constant one. Desai goes on to offer a political analysis of Gujarat since its formation. She suggests that the discontent of the upper and middle castes with the marginally redistributive policies and rhetoric of the Congress has been expressed in a range of opposition parties and movements. These have coalesced in the form of the BJP and the Sangh Parivar. Hindutva therefore is an expression of the political and politico-economic agency of Gujarat's dominant propertied classes, along with some other aspirational groups. With the current Gujarat Congress Party embracing 'soft Hindutva', and giving up on building a subaltern coalition, the consolidation of the elite behind the BJP has been strengthened. This ruling elite thrives on a development model which guarantees it a place at the heart of Gujarat's politics and economics.

Ward Berenschot's paper investigates the fascinating institution of the middleman or fixer. The paper complements Desai's macro view of Gujarat politics, and Vinayak Chaturvedi's discussion of the agency of the downtrodden in a time of Hindu nationalism. The middleman of Berenschot's analysis, in fact, plays an important role in connecting the different levels. The fixer is able to deliver votes to parties in a system based on patronage. But he is also 
important in driving the services of the state to the populace. In the process, the fixer regenerates and maintains the importance of democratic politics, and the centrality of the government in the lives of the poor and lower-middle classes. In this context, Berenschot focuses on a fixer who works for the BJP. This man's rise to his current position was coterminous with the decline of the Congress. This was accompanied by a change in the pattern of channelling votes through local notables, which the Congress had depended on. This in turn created the space for a new breed of fixer, including fixers from the Dalit jatis that the BJP was targeting in its new Hindu constituency from the mid 1980s. The shift of some lower castes to the BJP's fold, according to Berenschot, needs to be seen at least in part through the lubricating role of the fixer.

Vinayak Chaturvedi also investigates the draw of Hindutva to the downtrodden. He is concerned with the nature of colonial, nationalist and post-Independence democratic politics that has systematically marginalised particular communities, viz. those classified as 'criminal tribes' by the colonial state and as denotified nomadic tribes (DNTs) by the post-colonial state. Hindutva now offers a voice to some of these groups in Gujarat, for example the Dharalas, Charras and Waghris. The participation of the latter in the violence of 2002 has been recognised: however, much of the existing literature attributes this to their being misled, or being bribed with money or alcohol, or generally not knowing the consequences of their actions. Instead, Chaturvedi asserts that DNT involvement in recent episodes of conflict should be read as the 'dark side' of political society, a phenomenon whereby it is not impossible to conceive of the victims of society becoming killers in genocides. This 'dark side', however disorienting it may seem from the outside, is still an expression of agency, that is, a conscious attempt by the marginalised to be included in a nation and to write their own history. The Dharalas and groups like them are subjects of Gujarat's politics, including the 
politics of Hindutva. Chaturvedi's paper is an appeal to see them as such, while also alerting us to the methodological challenges of studying under-explored groups as agents of politics and history.

Hindutva may seem to characterise Gujarat today. However, the remaining papers in this special issue focus on the quotidian religious influences that contest and blur such a definition. Edward Simpson explores the explanations of local men and womenfor a geological phenomenon, an earthquake in 2001, which often centre on religious reasoning. Religion here can be spelt with a small ' $r$ ', defying the macro categorisations of sociology and politics. At this level, earthquakes and other disasters have become fathomable as the wrath of god, or punishment for co-religionists who have abandoned local saints and traditions in the pursuit of pan-religious reform. Here, explanations for the disaster often slide across formal religious divisions, with neighbours, irrespective of religious affiliation, seeing common themes of punishment, historical justice and balance in the disaster. Realities of social and economic change, class divides, and inequality provide underlying explanationsbeneath the layer of 'chance' and religious justification. Thus, Simpson demonstrates, 'the religious reasoning of blame narratives is shown to have a broader cultural existence outside the boundaries of particular religious identities'.

Also demonstrating how religion becomes an explanatory window for ongoing events and concerns is Farhana Ibrahim. The protagonists of her ethnography of Kutch too have unique, personalised, and at the same time highly-complex political explanations for the earthquake of 2001. Going away from the blame narratives of many of Simpson's interviewees, some of those researched by Ibrahim see the earthquake as an opportunity. Here is a geological shakeup that may well be a portent of the re-emergence of the mythical river Saraswati from the 
earth's innards. The earthquake could also be a sign that the Indus, now across the Pakistani border in Sindh, will change course to flow in Kutch — as the Hindu nationalists imagine was the case in Gujarat's glorious past. The theme of sanctity runs through Ibrahim's paper. She highlights the rituals of secrecy, patrolling and protection that the state repeatedly performs in order to delineate the border of a country or province as a uniquely revered space. The border then, both for religious nationalists intent on protecting the holy and reclaiming the distinctive boundaries of the region, and for the state intent on guarding and reinforcing these artificial boundaries, becomes the inviolable core of the nation.

Of course for the regular residents of frontier spaces, such as the Jatts in Ibrahim's story, cadastral and cartographic constructs have little meaning. As in the past, they continue to meander across the official India-Pakistan frontier. This is done physically, i.e. illegally, but also in an imaginary sense. The boundaries of the region are constructed through the sacred geography of the life of the Jatts' saint, Mai, who was born and buried in Sindh, but who performed several miracles in Kutch. The Jatts thus formulate their own regional boundaries based on ideas of history, religious belief, marriage, kinship and trade. These alternative imaginaries of the region constantly challenge formal authority, i.e. the authority of the state, but also of religious orthodoxies of various dispositions.

The taken-for-granted boundaries of religion and region are questioned by Suchitra Sheth in her reconstruction of the iconic moment of the subcontinent's partition in 1947. One hardly associates Gujarat with the havoc and violence of Partition, and even when this event is recalled, it conjures images of the migration of Muslims to Pakistan and Hindus to India. Sheth blurs these certainties through a paper rich in interviews with Sindhi immigrants to Gujarat. She brings out the diversity in the experience of a common event, based not on 
macro religious affiliation, but on caste and sub-caste, gender and community. There is little in common between the migratory experiences of upper-caste Hindus and Dalits, just as there is little overlap in their lives in Gujarat today. Moreover, despite the formal divide and even bitterness of Partition, common dialects, and a shared history, class and cultural practices, continue to bind those on either side of the international border.

In this special issue's final take on the everyday practice of religion in Gujarat, Carolyn Heitmeyer focuses on a commuter town near Ahmedabad. Mahemdabad is quite removed, though not totally divorced from, the homogenising, often violent politics of identity that are playing out in contemporary Gujarat. Hindu nationalists and Islamic reformists both have a presence in the town, with some of the former even having participated in the violence of 2002. However this feature does not dominate the landscape. Sufi shrines are a significant alternate presence. The author investigates religious practices through the lives of three Sufi saints or pirs, and through the influence they have in the community across formal religious boundaries, and on caste and class status. The blurred boundaries of Heitmeyer's research extend not just to devotees but to the pirs as well. They have acquired their aura and status through the lives they lead, rather than through birth. By birth, they are men of variable caste and family background. At the same time, the devotees of these saints are well aware of their own religious affiliations, visible for instance in the different rituals through which Hindus and Muslims express their reverence at the Sufi shrines. Thus, crucially, the author warns us against seeing the presence and influence of Sufism as somehow automatically indicative of a syncretic culture or religious harmony. That the pirs continue to draw various devotees is down to their spiritual power, not social syncretism. Devotees hope to draw on this power in order to access the divine in whatever form this may be. Religious identity is thus neither 
defined nor questioned in these Sufi sites, which are primarily locations for the everyday practice of religious belief.

\section{Conclusion}

In sum, this special issue adopts a spirit of challenge and questioning. It remains wary of analytical absolutes, be they of religious opposition or religious harmony. Instead, as a collective endeavour, it is able to highlight the multi-dimensionality of religious existence in Gujarat. Gujarat is not a land of Muslims and Hindus, but of millions whose religious sensitivities may — or may not—engage with conflicting interests and ideologies. In keeping with this multi-facetedness, we believe that we have been able to achieve at least three objectives. First, we question the Eurocentric modernisation trajectory that this Introduction stated at the outset. Instead, as is obvious, we highlight the consistent presence of religion as faith as well as identity in this region. If modernity and religion were ever opposed and contradictory, this is not the relationship between them that we observe in Gujarat. Second, we challenge narratives of homogenisation of the region, as well as religion in the region, by opening the discussion to themes of plurality around, resistance to, and everyday circumvention of the dominant and visible. A region is not an object in itself, and the regions constructed by Gujaratis in different parts of the State may overlap and intersect; they may stand as inclusive or exclusive. The contingent strands of religion and religiosity are then woven into this regional diversity. Third, we seek to bring together many of the ongoing narratives and debates on religion, showing religion as a source, simultaneously, of conflict, and also of well-being, identity politics, quotidian faith, and much more. The web of religious experience and possibilities that we construct is perhaps analytically achievable only in the focused spatiality of a study such as ours. However, our findings have relevance to the resurgence of studies of religion more broadly. 
